\title{
Achieving agility using business model stress testing
}

\author{
Harry Bouwman ${ }^{1,2}$. Jukka Heikkilä ${ }^{3}$ - Marikka Heikkilä ${ }^{3}$. \\ Carlo Leopold $^{1} \cdot$ Timber Haaker $^{1}$
}

Received: 31 January 2016 / Accepted: 22 December 2016/Published online: 18 February 2017

(C) The Author(s) 2017. This article is published with open access at Springerlink.com

\begin{abstract}
Business Model (BM) Innovations aim at making systemic changes in the business logic of companies when they are bringing innovative products and services to the market. Companies should be sensitive to changes in their business environment and able to modify their BMs in an agile way. To assess the agility of BMI during specific market entry situations, this paper uses a method that stress tests the value proposition and the components of a BM against contingent uncertainties. We present three qualitative case studies of companies that differ in their market entry approach. Starting from their strategic orientation, these case companies' stress test their Business models and BM components, using a scenario-based identification of uncertainties. The BM Stress Test method contributes to a quick understanding of the
\end{abstract}

Responsible Editor: Hans-Dieter Zimmermann

Jukka Heikkilä

jups@utu.fi

Harry Bouwman

W.A.G.A.Bouwman@tudelft.nl

Marikka Heikkilä

marikka.heikkila@utu.fi

Carlo Leopold

carlo.leopold@gmail.com

Timber Haaker

timber.haaker@innovalor.nl

1 Delft University of Technology, Delft, The Netherlands

2 Åbo Akademi University, Turku, Finland

3 University of Turku, Turku, Finland components their BM needs to monitor, reconsider, or improve. Such stress testing helps enhance business agility. The research contributes to market strategy and business modelling research by introducing BM Stress Testing as a new method that can achieve and maintain agility regarding BM uncertainties.

Keywords Business model $\cdot$ Business model innovation . Business modelling $\cdot$ Market entry $\cdot$ Agility $\cdot$ Stress testing

JEL Classification L10 $\cdot \mathrm{L} 11 \cdot \mathrm{M} 11 \cdot \mathrm{M} 13 \cdot \mathrm{M} 15 \cdot \mathrm{M} 31 \cdot \mathrm{O} 31$

\section{Introduction}

Business Models (BMs) are acknowledged as effective instruments for strategy execution (Casadesus-Masanell and Ricart 2010; Cortimiglia et al. 2016; DaSilva and Trkman 2013; Teece 2010; Zott and Amit 2010). They are combined with the designing, analyzing and implementing of new innovative concepts that can enhance the competitiveness of companies or business networks (Bock \& George 2014). New BM innovations (BMIs) can, for instance, be extensions of new technological inventions, new usages of existing technologies, or making the shift from a product to a service- oriented logistics. We thus define BMIs as systemic changes in the business logic of companies when creating and capturing value for both customers and companies. In essence, business logic describes how a single firm, or a network of firms, by collaborating on a strategic (eco-system) and operational (process) level, can bring innovative products and services (or bundles of products) to the marketplace successfully (e.g. Cortimiglia et al. 2016). Even though it is acknowledged that companies should be sensitive to changes in their business environment and able to modify their BMs in an agile way, to our 
knowledge there is little research that has discussed how this agility of BMI is best achieved.

Bouwman et al. (2014) argue that BM design needs to start in the early phases of ideation, in a parallel timeframe to the ideation of new products and services. We take this argumentation one step further by arguing that continuous development and/or testing of BM under different scenarios actually leads to agility. Agility, as a concept applied in organizational theory and manufacturing, is defined as the ability to adapt and respond to change and uncertainty (Volberda 1996, 2004; De Toni and Tochia 1998; Sherehiy et al. 2007) that is related to policy, regulator or regulations, market, competitor behavior, or fundamental technology changes (De et al. 2009). Thus, we not only promote agility as a continuous iteration during the different ongoing stages of the design of an innovative product or the design of a service in combination with a Business Model, as is common in agile software production (Beck et al. 2001), or in information system development (Conboy 2009). We also see agility as an outcome in itself, e.g., as an improved capability to respond to unforeseen changes. Here we also explore how this process can be undertaken successfully to address different market (entry) conditions and uncertainties (e.g., derived using scenarios).

The BM literature and its discourse has brought into clearer focus the view that Business Modeling should be seen as a learning (Itami and Nishino 2010) and a planning process wherein BM assumptions are both articulated and tested (McGrath 2010). Therefore, in addition to tools like Canvas (Osterwalder \& Pigneur 2010), there is a clear need for methods that will help companies continuously analyze BMs in a way that achieves agile design and eventually produces robust, but versatile, BMs that can handle change and uncertainty.

This paper studies and applies the stress testing method for BMI. The term 'stress test' refers in generic terms to "A test designed to assess how well a system functions when subjected to greater than normal amounts of stress or pressure", (Oxford Living Dictionaries 2016). We thus define BM Stress Testing as a systematic analysis of the robustness (i.e., long- term viability as well as feasibility) of BM components such as a value proposition, revenues or cost structure - based on different future conditions (or uncertainties). We prefer stress testing to sensitivity analysis, however, because our attempt is not to analyze a business model innovation as such, but rather its viability in those business realms that are most likely to change.

A BM Stress Test helps managers understand how their BM meets potential technical, regulatory, or market conditions, and related uncertainties. The effort enables them to identify and make changes to the BM or BM components in the early phases in a quick and efficient way, thereby shortening time to market and avoiding implementing a business model that is in conflict with actual circumstances. BM stress testing uses scenarios that are related to uncertainties in combination with $\mathrm{BM}$ ontologies. By analyzing and estimating the impact of different scenarios on BM components, we can identify the components that are most vulnerable in certain scenarios and thus need additional attention.

Hence, our objective is to explore how the use of a specific Business Modelling method, BM Stress Testing, can contribute to agility in design and innovation processes of a BM. We can also contribute to agile BMs' ability to adapt to possible changes in technology, regulation, competitor behavior, and/ or in markets. Consequently, our contribution to BM design and innovation practices is pragmatically oriented, but not so much in terms of developing a theory on Business Model Innovation. We explore and illustrate using three case studies, how BM Stress Testing can help identify the sensitivity of a $\mathrm{BM}$ to uncertainties, and also how to make managers more agile by being able to identify the components of a BM that is affected by such a change.

To achieve these objectives, we first discuss the literature on market entry strategies for product or service innovation, e.g., High-End Disruption, Low-End Disruption and NewMarket Entry. Thereafter, we focus on agility as it relates to BMI. Then, we describe our BM Stress Testing method and show how to map the uncertainties with the components of the BMI and how to evaluate the possible impacts on specific BM components. Our study approach makes it possible to compare these cases under three different market entry conditions. Finally, we present the results of the BM Stress Testing cases and discuss the insights, lessons, and limitations of BM Stress Testing for practical implementation and offer opportunities for related future research.

\section{Literature review}

This study is motivated by our recent research on innovating new business models. Those findings imply that an iterative and agile process for utilizing market information, aligning and leveraging resources, is beneficial to companies (Heikkilä et al. 2015; Chou et al. 2014). In earlier research, the opportunities for and threats to an innovation have been found to be contingent to the outset situation.

Innovation and market entry Many leading companies are spending hugely to maintain their competitive positions and create innovative and better products for their customers (Christensen 2006). Exploitation and extension of the product life cycle of existing products mainly drive sustaining strategies. However, the dilemma of such a high-end (sustaining) product strategy is that a company aiming at bringing better or converging products in established markets takes the risk of developing too complicated a range of products (Christensen 1997) or offering extra performance not valued by the average customers (Norman 1998; Christensen et al. 2015). Another 
uncertainty with this strategy comes from the growth of complexity in the markets. For instance, often the companies must comply with regulations and specialized codes-of-conduct, as advocated by authorities. This situation increases the incumbents' production and transaction costs and creates complexity in both maintaining and implementing BMs (Christensen et al. 2015). On the other hand, these complications also serve as obstacles for new entrants into the same market, especially if that market entry requires heavy investment in organizing structure, processes, and capabilities (Galbraith 2014).

Newcomers aiming to enter the market need BMs that can outperform the incumbents with novel, sometimes initially not even superior, solutions while providing in the long term substantial cost and performance improvements over their incumbents' products. Typically, this calls for more efficient BMs to serve the large customer segment better, or at a lower cost, thereby disrupting the incumbent's business. Christensen et al. (2009) divide these market entry strategies into two categories: "Low-End Disruption" means that some customers are served better by a company providing a simple unbundled service at a more affordable price (e.g., Ryanair vs. British Airways); and "New-Market Disruption", which takes place when a company is able to serve customers who were not previously served by existing incumbents. New-Market disruption, however, calls for special skills so as to be able to reflect on uncertainties related to new ecosystems and industry structures and new BMs and activity system architectures (Doz and Kosonen 2008, p. 27; Kim and Mauborgne 2005). This kind of disruption is claimed to be boosted by networked innovative activities (Christensen et al. 2009), where and when the incumbents seem to be at their weakest. In sum, New-Market entry is about design, thinking out of the box, and managing implementation to potentially changing market conditions (Christensen et al. 2015).

Depending on their selected market entry strategy, companies are facing differing kinds of uncertainties that may affect the viability of their business idea. Therefore, we suggest that these uncertainties should be taken explicitly into account when developing the innovation and the BM.

Innovation and business modelling The product and service design literature is characterized by formal methods that help translate customers' needs into plans to achieve design quality that meets those needs. Examples are New Product Design (Takeuchi and Nonaka 1986), Stage- Gate model (Cooper 1990), Quality Function Deployment (Cohen 1995; Chan and Wu 2002), Service Blueprinting (Shostack 1984), Service Concept Analysis (Goldstein et al. 2002) and New Service Design (Menor et al. 2002). Goods and services are today closely interrelated (Vargo and Lusch 2004), e.g., as product-enabled services or 'servitization' of products or product-service-bundling. As a result, product- and service- related logic has become more and more common and indeed integral to both business model design and innovation. Early examples of servitization are provided by Bullinger et al. (2003), as well as Karni and Kaner (2007). The approach can help product-oriented companies switch to a more service oriented approach, i.e., paying special attention to reusing service components. These approaches are also characterized by a kind of phasing model, the number of steps to take, and/or formal analyses to be executed. In practice, many of these approaches are building on existing resources that are very suitable for 'feasible' and sustaining development strategy. On the other hand, these methods seldom make an explicit strategic connection to either disruptive Low-End, or New-Market entrance.

Also, in the BM literature, whether taking strategic management or marketing perspective (Zott and Amit 2010; Osterwalder and Pigneur 2010) or an Information Systems perspective (Heikkilä et al. 2010; Bouwman et al. 2008; El Sawy and Pereira 2012), the method recommendations follow primarily a processes model, being confined to value creation or ICT implementation of the designed BM. On the other hand, the activity system perspective (Zott and Amit 2010) is rather holistic and high level, but without providing practical implementation guidelines. The Business Model Canvas as developed by Osterwalder and Pigneur (2010) is in our view a brainstorming tool, that is mainly focused on marketing new products and services at a high level, while still has a gap in implementation on an operational or ICT -level. Fritscher (2011) tried to bridge this gap by developing a link between $\mathrm{BM}$ and Systems Architecture (for recent developments, see Otto et al. 2015; Fritscher and Pigneur 2015). The unit of analysis is a specific business with a focus on business marketing and value creation process for a specific customer segment.

CSOFT (Heikkilä et al. 2010) and STOF (Bouwman et al. 2008) share some communalities in terms of the ontology of BM (consisting of Services, Technology, Organization, Finances, and the Customer Relationship), but also pose some differences. CSOFT focuses on differentiated product-customer segments and derives quantifiable performance and quality metrics explicitly from the strategies in the context - indeed, the innovativeness of a BM is essentially subject to strategic goals, and its efficiency arises from the componentization of business operations. STOF is more focused on technological architectures and platforms in combination with value networks and ecosystems that bring about a specific service or product. In STOF, the service or product is the unit of analysis, which provides a basis for objectives setting, road mapping, and stress testing of the practical implementation of tentative services on the market (de Reuver et al. 2013). The above BM approaches distinguish the components related to (1) the core service or product- like value propositions, segmentation, service/product offering, and channels; (2) the ecosystem such as roles and key actors, actors resources, 
and capabilities; (3) technology components, such as applications, technical architectures, or platforms used, or (4) financial arrangements like investments, costs, revenue and pricing models, as well as risk and revenue sharing (Bouwman et al. 2008; see also Chesbrough 2010).

Market entry strategy in business model analysis Market entry orientation, such as a High-End product strategy, LowEnd, or a New-Market disruptive strategies, is seldom explicitly analyzed when designing or innovating BMs. While CSOFT and STOF methods can support all three market entry strategies, in actual practice, the focus of STOF is often on disruptive innovative technologies. VISOR (El Sawy and Pereira 2012), in turn, is a relatively new BM method. VISOR focuses on changes in the Digital Businesses' Value proposition, Interfaces, Service platforms, Organizing and Revenue/Cost sharing for common language, business options' viability analysis, and the complexity of inter-related issues of BMs. BM Cube (Lindgren and Rasmussen 2013) focuses, like STOF does, on Business Models of value networks, but adding competencies as one of the seven building blocks of a BM.

Agility and BM We approach agility from two different perspectives: agility as an outcome, and agility as a way of working in the design or innovation process of BMs. The first view on agility is a contingency perspective, i.e., how organizations can be more adaptive to uncertainties and changes in their environment. Businesses are expected to become more agile and adaptive to their environments (Volberda 2004). The latter approach like XP (Beck and Andres 2005), Scrum (Schwaber and Beedle, 2002), DSDM (Stapleton 1997) and FDD (Coad et al. 1999) has been introduced in the context of software development as an alternative to the traditional, plan- driven and heavy methods focused on documentation and process compliance (Lee and Xia 2010). Agile development views the development process to be dynamic, evolving, and organic, instead of predefined, mechanistic, and static (Lee and Xia 2010), and this seems to apply to platform- based services as well (Chou et al. 2014).

The agile approaches welcome changing requirements and aim at satisfying customer needs via iterative development cycles (e.g., sprints) and co-design with customers and users. In this way, these approaches align development efforts with business values by making people from both business and design work together. For example, the Spotify model has become a recently popular means to achieve agility in product and service delivery (Kniberg and Iversson 2012). In line with the above process, we see a benefit from combining the business view with agile development methods for products and services. The common design artifact could be a BM - visualized using ontologies and tools - and serving as a useful boundary object between the stakeholders and the developers
(Bouwman et al. 2012; Heikkilä and Heikkilä 2013). This extension to the development process will require tools for the team to work on the business model in concert with the technical development of that product or service (Heikkilä et al. 2015).

\section{The business model stress test}

To our knowledge, stress testing for business modelling was first suggested by Bouwman et al. (2012) as the means to improve the implementation of BMs and going beyond BM being "merely a strategist and marketing pastime." (Bouwman et al. 2012, p. 24). They drafted the method below, and it has been elaborated on further to match the iterative nature of product and business development for agility better (Heikkilä et al. 2015).

BM Stress Testing is a method used to evaluate the BM design against market scenarios, regulatory uncertainties, or technological uncertainties, and it leads to a changed BM that is more robust. In this way we can enhance the responsiveness and agility of the BM to the market situation. Stress Testing is especially utilized in a context where uncertainties regarding government behavior, the behavior of competitors or fast changing technologies affect the robustness of a Business Model. BM Stress Testing aims to make explicit in which scenarios the BM components might be at stake. As a result, the 'fit' of a BM with a set of future market conditions, regulatory regimes, and/or technological landscapes can be more precisely determined.

In Fig. 1 we give an example to illustrate how BM components are related under two different scenarios that reflect uncertainties due to regulatory options (notice that the components of the STOF ontology used are target group, value proposition, service offering, context of use, effort for customer, and customer relationship). The Heat Signature provides an overview of the sensitivity of the BM to alternative future uncertainties that may be important to the business. Figure 1 . shows a spreadsheet- based software tool that makes it possible to express Stress Test results in line with different BM ontologies, for instance, STOF or Canvas. The rows present the different BM components, and the columns present two scenarios that deal with an uncertainty related to legislation. The four colors represent the degree to which these components are affected, while the text field explains the motivation according to the involved stakeholders.

BM Stress Testing method is qualitative in nature and follows a six- step iterative plan.

1. Describing BM: BM Stress Test method is independent of BM ontology, so any BM, be it Canvas, STOF, VISOR, or BM Cube, can serve as the starting point for the Stress Testing (see Fig. 1). The details about the particular BM are often already described at the outset in multi-format, 


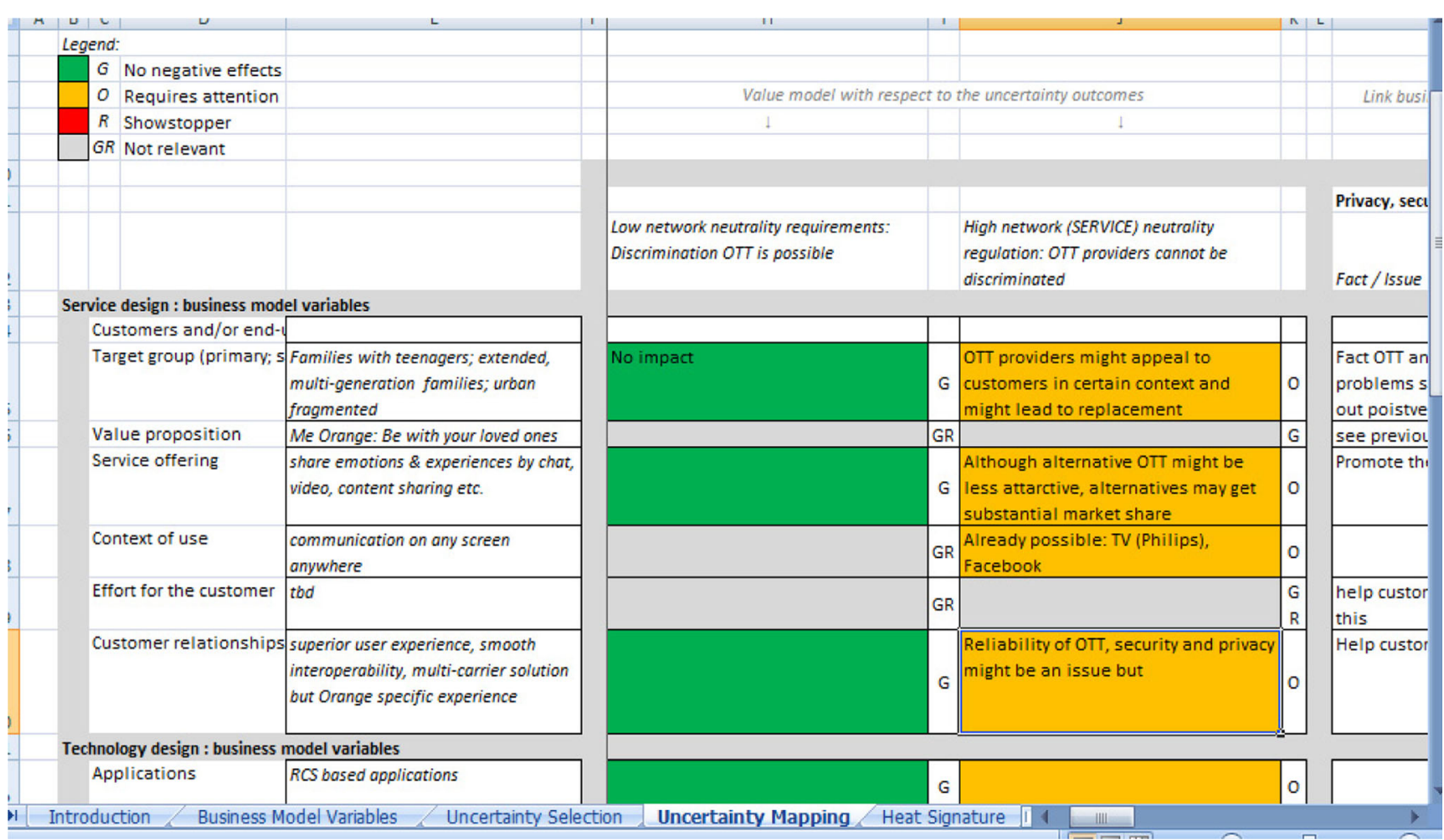

Fig. 1 An example of the outcome of BM Stress Testing showing two alternative scenarios related to regulatory uncertainty

rich documents. However, it is also possible that the $\mathrm{BM}$ is tacit in the beginning; however, in both cases, the BM is made explicit to the specific ontology in use and articulated to become a suitable template.

2. Selecting uncertainties. Several approaches for the selection of uncertainties exist; for example, the uncertainties can be a result of a brainstorm with the involved stakeholders. That brainstorm can take the form of a PESTLE ${ }^{1}$ -analysis from multiple perspectives. Stakeholders are involved in selecting these uncertainties and getting the facts 'right' (read: confirmed and agreed) and also complete. Typically, we select specific influential outcomes of the uncertainty and confront these with the BM in the next steps so as to assess the impact of an uncertainty on the BM elements more concretely. The selected outcomes are typically at the opposite or extreme ends of the possible uncertainty outcomes, thus resembling the idea of contrasted scenarios. Experience shows that a proper and limited selection of uncertainties makes Stress Testing more manageable.

3. Mapping BM to uncertainties. The actual BM Stress Test consists of a confrontation between the selected uncertainties and their outcomes and the components of the BM. First the relationship between the uncertainties and

\footnotetext{
${ }^{1}$ PESTLE meaning political, economic, social, technological, legal, and environmental factors. Sometimes is also expanded to identify other demographic, inter-cultural and ethical factors in the macro-environmental scanning, analysis, and decision-making.
}

the BM elements is described in terms of facts and issues. Facts explicate those parts of the factual description of a BM element that relate to the description of an uncertainty. For example, if a BM element involves 'using personal data of customers' and an uncertainty is about 'regulation for using personal customer data', then there is a clear factual relationship between these two, i.e., the 'BM element uses personal customer data'. How this factual relationship should be valued is part of the next step and depends on the specific outcomes of the uncertainty. Issues concern the questions or dilemmas that an uncertainty raises regarding a BM element. Finally, a clear picture of how uncertainties relate to BM elements emerges.

4. Heat Signature. This step is about determining and assessing the possible impact of specific outcomes of the uncertainties on the BM elements. A 'Heat Signature' is prepared, using a coloring scheme to indicate the impact of a specific uncertainty outcome on a particular BM element:

- Red indicates a possible showstopper; if the specific uncertainty outcome occurs, then the BM as defined will not be possible anymore.

- Yellow implies that if a specific uncertainty outcome occurs, some negative influence is likely. Consequently, attention is required to tackle that uncertainty.

- Green indicates that no negative effects/influences are to be expected from the uncertainty outcome. 
- Grey indicates that uncertainty has no relevant influence on or for the business model.

The Heat Signature takes the form of a matrix with the BM elements positioned vertically and uncertainties and outcomes placed horizontally. In the cells in this matrix, the motivation(s) should be added to explain why an impact vindicates a certain color. This step is particularly important for understanding and analyzing a Heat Signature. It is the grounds for finding ways to make the business model more versatile and robust for any changes.

Analysis The Heat Signature provides insight into the weaknesses of the BM by making the vulnerability of certain BM elements visible. Potential showstoppers are identified, and therefore, the BM Stress Testing provides not only the visual coding, but also qualitative description of the problems and the BM design choices in the background.

Pattern analysis Coloring can also be analyzed in combination to reveal patterns of colors that may point to:

- $\quad$ preferred uncertainty outcomes (scenarios), i.e., a specific outcome shown to be consistently favorable for the BM; or alternatively, consistently shown to be negative,

- inconsistencies between BM choices, i.e., the impact of an uncertainty outcome is favorable for some BM elements, but not for others, whereas for the alternative uncertainty, it is the other way around,

- BM choices are invalid in both selected uncertainty outcomes. As the selected outcomes are at both ends of the uncertainty outcome spectrum, this result is usually an indication of a serious issue in the BM that needs to be analyzed and remedied (e.g. with a root-causes -analysis).

Creating sub-views on the Heat Signature is a way to structure the analysis, zoom into problem areas of the business model and/or find or unravel the reasons why certain parts of the business model appear better than others. For example, a view per business model element row accumulates over all uncertainty outcomes, and that view provides an indication of its overall robustness against uncertainties. It also helps to figure out why a certain BM element yields an overall red or green, from the explanation in the cells. On the other hand, by viewing the results per uncertainty outcome (column) you get an understanding which BM elements are affected most. These patterns aid in the systematic evaluation of the Heat Signature of a scenario. Stress Testing reveals why certain choices in the BM create problems, and also what are the proper means to tackle those problems.

\section{Conclusions}

After analyzing the robustness and vulnerability of the BM, it is typically time to make concerted recommendations that address the weaknesses or improve the consistency of the BM to make it more robust or versatile. In Stress Testing, such improvements can be generated on short notice. A well documented reasoning behind the choice for a specific coloring is the basis for both an analysis and improvement. This process helps in both directing the initial stages of BM designs and in revising BM Innovations.

\section{The case studies methodology}

Our research follows a pragmatist research tradition and an action design research approach in the three cases. (Hevner et al. 2004; Sein et al. 2011; Van Aken and Romme 2009; Verschuren and Hartog 2005). We actively participated as facilitators and researchers to 'beta-test' the BMs of three small and medium-sized case companies. We also co-designed with these companies the artifacts relevant for the case organizations to help solve their business problems. According to Cole (2005), these activities make our study a research that combines action research and design research approaches, later labelled as action design research (ADR) by Sein et al. (2011). As such, applying ADR in the context of these cases helps us to understand how BM Stress Testing helps real businesses deal with authentic problems. The object of ADR is what Sein et al. (2011) call an ensemble artifact, i.e., an artifact that is composed of technological and social elements. Here it is the stress- tested BM.

For this study, we developed a case study protocol that describes the research process (generic stages from Sein et al. 2011, Fig. 2):

- Stage 1. Three case companies wanted to systematically analyze the agility and robustness of their novel BMs (as artifacts). Our problem formulation was practice-inspired, building on theory-ingrained recommendations for developing BM in the context of innovating.

- Stage 2: Each participant from the case companies answered a questionnaire before and after the actual BM Stress Test workshop, building, intervening, and evaluating emphasized reciprocal, concurrent mutual learning among the different project participants during the workshops.

- Stage 3: Reflection and learning emphasized the refinement of the artifact during and after the workshops, as suggested in the ADR process. The stress-test results were reflected in the design and improvement needs of the original BMs.

- $\quad$ Stage 4: The insights from these three cases were summarized further to formalize both the practical and the theoretical outcomes and a tentative generalization. 
Fig. 2 The stages of action design research (Sein et al. 2011)

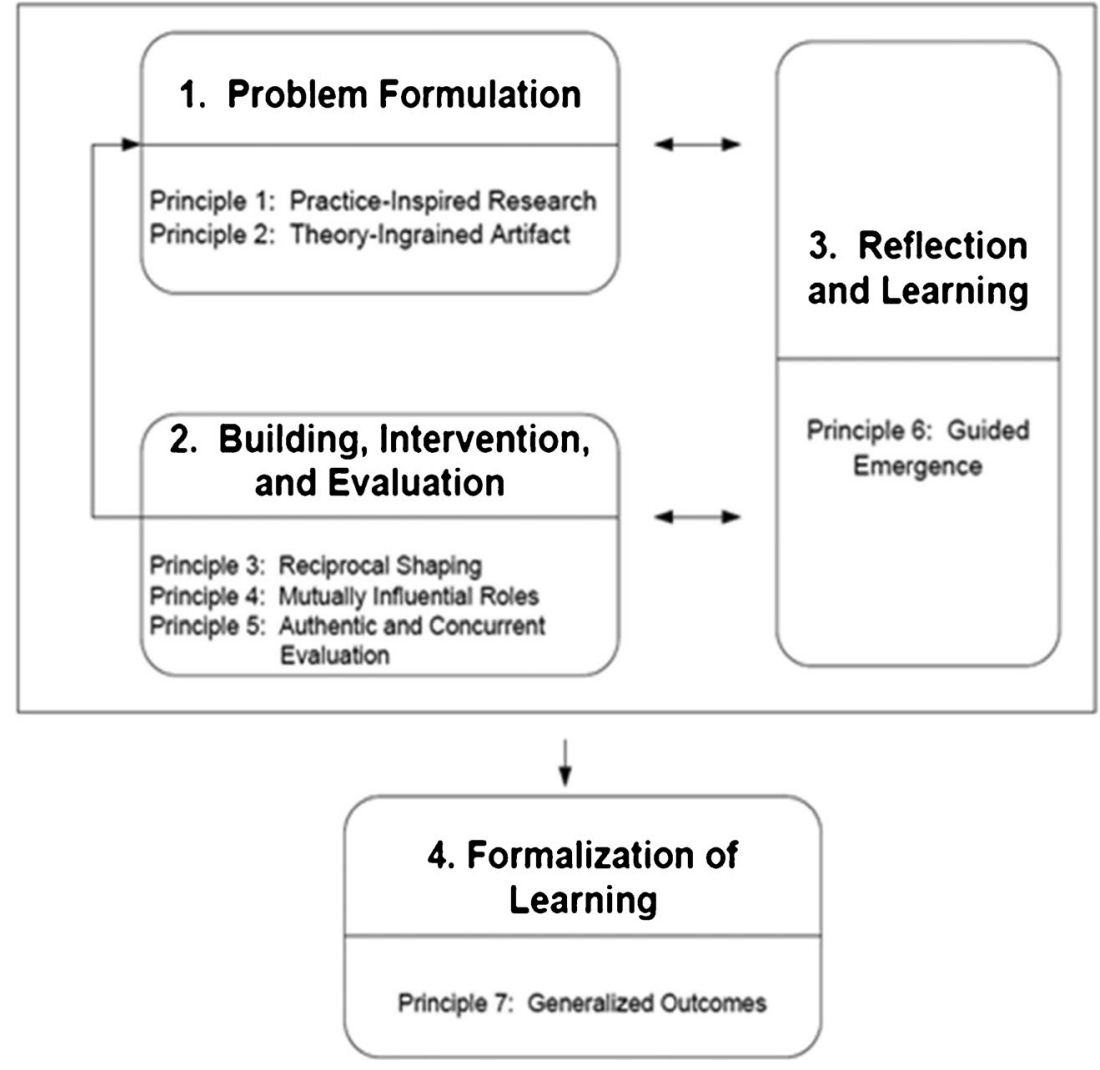

Case selection We contacted three design cases with both theoretical and pragmatic considerations in mind. The three cases (1) represent different industries (2) they have different market entry strategies, and (3) they make use of three different ways of combining BM design or innovation with developing products or services (see Table 1). All three case companies agreed to their active participation:

- Zo-Dichtbij is a fresh start-up that currently has a not-forprofit legal status (2016). The company is a spin- off from a university research project. Its activities are close to a cocreative Living Lab-environment for the development of a multi-sided market health and well-being platform. ZoDichtbij's platform makes matches between (1) endusers looking for services, (2) service providers to market their services, and (3) government to coordinate and control the care (Keijzer-Broers et al. 2015). The primary stakeholders of the company, including the core ecosystem participants, have extensive experience in BM. The case organization follows a Low-End disruption strategy to introduce affordable, targeted services and lower search and matching transaction costs. Because the company is in the early phases of business development, there is no revenue yet. In Zo-Dichtbij learning is a core capability and a requirement for the development of the multi-sided BM. Zo-Dichtbij pays attention to BM almost weekly, mainly for (re-)structuring its activities to follow up on its progress and iterate its BM. The disruptive BM element of Zo-Dichtbij is switching the business from the present, expensive service channels to an online platform with only a fraction of operating and transaction costs for all the parties.

- Holland Container Innovation (HCI) is a mature private company with some revenue. The company is developing a foldable $40 \mathrm{ft}$. sea container as a niche product among the existing standard intermodal freight containers. HCI is the owner of the patent and they licensed a container builder to manufacture the needed number of containers for the customer, a shipping company. The shipping company pays the manufacturer, which in turn pays HCI a license fee. HCI adheres to a Sustaining Product strategy in a niche market. HCI sees itself as an innovative company that is a market leader in its niche. The company has a balanced view about taking risks and acts in an agile way when detecting new opportunities and ideas. The company is new to BM thinking - only one of the involved persons within HCI has had experience with BM thinking. The company is developing the technology first and only then modelling its business. Stress testing is also new to $\mathrm{HCI}$ and taking place in a later phase of the BM development. Their value proposition focuses on certified, fast, safe, and strong foldable containers by licensing their patented intellectual property of design and the trademark, 4 Fold. The company's core areas are product design, 


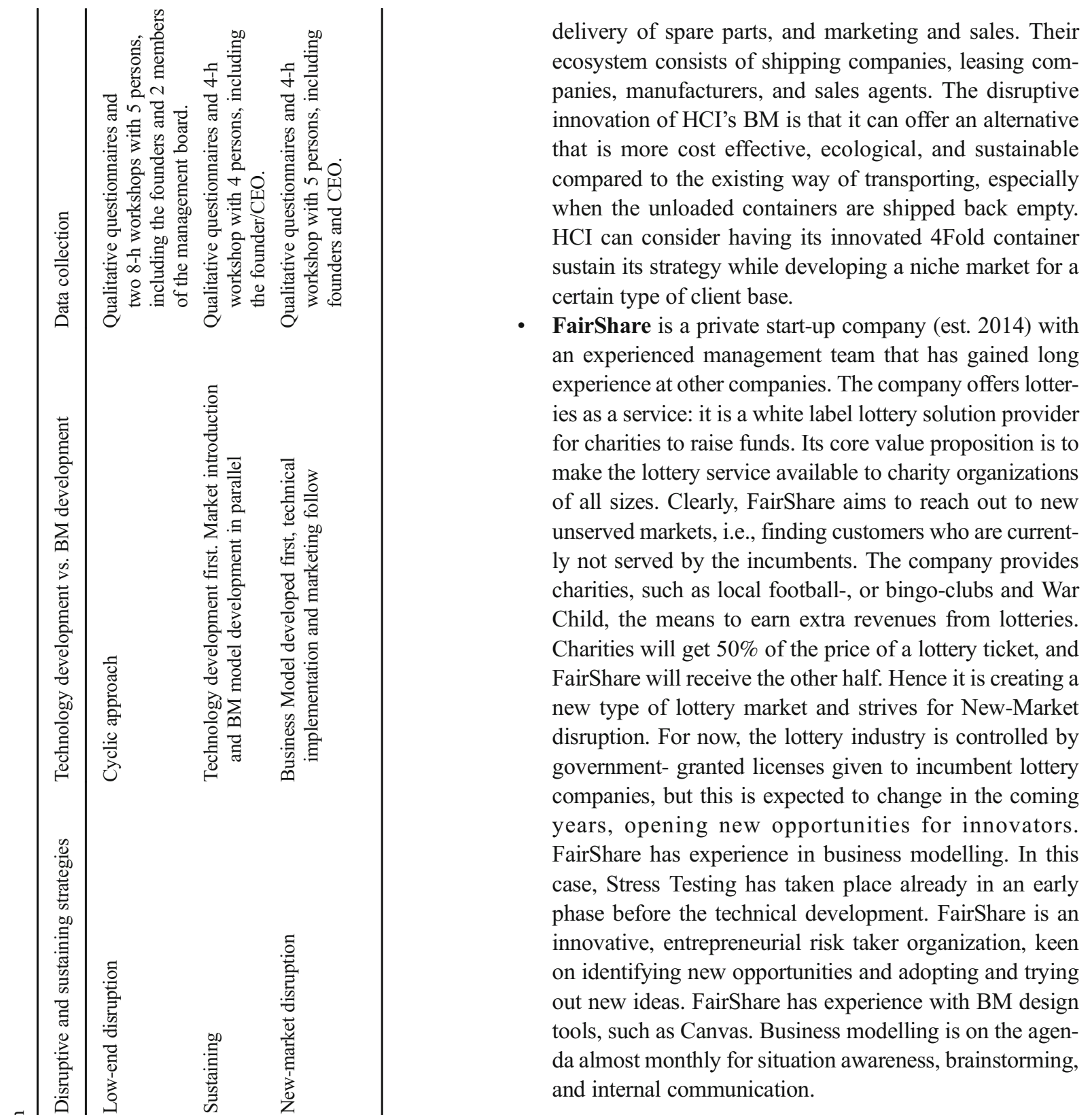

delivery of spare parts, and marketing and sales. Their ecosystem consists of shipping companies, leasing companies, manufacturers, and sales agents. The disruptive innovation of HCI's BM is that it can offer an alternative that is more cost effective, ecological, and sustainable compared to the existing way of transporting, especially when the unloaded containers are shipped back empty. HCI can consider having its innovated 4Fold container sustain its strategy while developing a niche market for a type of client base.

an experienced management team that has gained long experience at other companies. The company offers lotteries as a service: it is a white label lottery solution provider for charities to raise funds. Its core value proposition is to make the lottery service available to charity organizations of all sizes. Clearly, FairShare aims to reach out to new charities, such as local football-, or bingo-clubs and War Child, the means to earn extra revenues from lotteries. Charities will get $50 \%$ of the price of a lottery ticket, and FairShare will receive the other half. Hence it is creating a new type of lottery market and strives for New-Market disruption. For now, the lottery industry is controlled by government- granted licenses given to incumbent lottery companies, but this is expected to change in the coming in opportunities for innovators. FirShare has experience in business modelling. In this case, Stress Testing has taken place already in an early phase before the technical development. FairShare is an neven on identifying new opportunities and adopting and trying out new ideas. FairShare has experience with BM design tools, such as Canvas. Business modelling is on the agenand internal communication.

Data collection From all the cases, the data was collected first using a qualitative questionnaire and then in a workshop that involved both stakeholders and researchers. For Zo-Dichtbij we organized two sessions: two teams of five persons participated in sessions eight hours each. The other two case organization sessions took four hours with teams of 4 and 5 persons. In general, the sessions discussed the BMs as filled out, making use of different BM approaches e.g., the STOF model in Zo-Dichtbij, and Canvas in the other two cases, including the Stress Test itself and an evaluation of the results. The three cases in this study are positioned as depicted in Table 1 as they relate to Sustaining Strategy, Low-End Disruption, and NewMarket Disruption. After the positioning of these three cases 
by the case owners, we looked into how they dealt with the uncertainties in the different market scenarios and we collected them on a questionnaire before the workshop commenced.

The Stress Testing sessions were executed in the board rooms on company premises or at the university. The sessions were run by two of the authors of this paper. One of the authors and a co-developer of the Stress Test method facilitated the sessions. The other author observed the sessions and took notes on the process and the outcomes.

The team used whiteboard, instead of an Excel- based version, to stimulate discussions. The sessions were all recorded. We sent out a qualitative questionnaire a week before and after the session via email; first for preparing, and afterwards for evaluating each session. We used these data to profile he companies by their market entry strategy and by their experience with BM. The output of the session was also collected and stored. The dataset for this paper is a mix of quantitative and qualitative data. We coded the qualitative data using the guidelines of Miles et al. (2013), i.e., by building the coding on the core concepts: strategy, the way of working and agility.

\section{Results}

Next we discuss each case and the results gained from the Stress Testing.

In Zo-Dichtbij's BM Stress Testing workshops the participants discussed matters that might affect the vulnerability of the BM. Although the STOF ontology was used to design the BM initially, we expressed the results also in Canvas during the Stress Testing sessions due to the experience of some of the participants with Canvas. During both Zo-Dichtbij Stress Test workshops, the focus was on trends and uncertainties related to the LowEnd entry market strategy. Digital skills of pace and the consequences of an aging population, government regulatory measures on the market, and privacy statutes were all uncertainties that impact the viability of the BM. Furthermore, as expected for a Low-End entry strategy company, competition in the market was an important topic of discussion in both sessions. This issue included, e.g., the power of incumbents, such as insurance companies, in responding to Zo-Dichtbij's strategy. When these scenarios, trends, and uncertainties were analyzed, the biggest foreseen problems related to imitators. The most vulnerable parts of the BM for the Stress Test related to key partners, customer segments, and revenue models (see Fig. 3).

Zo-Dichtbij's scenarios focused on challenging the longterm strategic feasibility of the platform. The chosen Low-End strategy means offering service with lesser performance/ functionality compared to their competitors, which then lowers the price. The Zo-Dichtbij platform intends to serve a large base of customers with different revenue models for a sustainable business. Despite the emphasis on simplicity, the platform has a high upfront investment. Due to lower and competitive customer target prices, the return on investment is prolonged. The strategic feasibility depends on whether the platform will be used and by whom, and next, whether the customer base will grow fast and large enough to break even in a reasonable enough time to justify the investment.

Zo-Dichtbij considered the Stress Test method easy to understand, interesting, and providing new insights. The Stress Test outcome was also in line with the results of the questionnaire. The company was confident that a low-end disruption scenario is a viable strategy for Zo-Dichtbij, although changes to BM were then concluded: "The Business Model need to be more focused" and the "Business Model could work in this strategy with some adaptations [overcoming the vulnerabilities]". According to the financial manager of ZoDichtbij, the Stress Testing results provided the company with direction: "Now we can make a more clear choice for medicalrelated issues in the plan for caretakers, our platform has a lead on others. There are no comparable parties that can deliver a similar platform on a short notice."

Holland Container Innovations used Canvas to describe their BM. Their scenarios emphasized strong technology development, with a short- and a long- term focus (Fig. 4.). In the BM Stress Test, HCI's focus was on internal issues like improving the quality of the product, which is considered typical for organizations following a sustaining product strategy. While external uncertainties, such as adoption speed and transport costs, are important, the biggest uncertainty for $\mathrm{HCI}$ is related to the quality of the product and the decline of global cargo volumes. Also, the long- term feasibility of the product on a possibly changing market environment was discussed. Both shortand long-term scenarios were used to improve the chance of success for a sustainable business.

On the other hand, HCI Stress Testing revealed that the major issues are related to the value proposition, key activities, customer segments and revenue streams (see Fig. 5). For HCI, the Stress Testing sessions were thought provoking. It showed that even though a sustaining market strategy for HCI is viable, they must take market- related uncertainties seriously into account. One of the HCI members even welcomed Low-End disruptors/competitors: "A competitor with an improved version can be helpful in opening the market."

The FairShare workshop focused on long -term scenarios, starting from the feasibility of a new market strategy, i.e., identifying the biggest hurdles to overcome, and then determining whether the concept has any initial potential. The company has found the use of Canvas somewhat problematic, as it cannot deal with different stakeholders simultaneously. In practice, they have used several Canvases, one Canvas for each stakeholder. In this way the insight into 


\begin{tabular}{|c|c|c|c|c|c|c|}
\hline & \multicolumn{2}{|c|}{ Digital Skills } & \multicolumn{2}{|c|}{ Competition } & \multirow[t]{2}{*}{ WMO-Regulation changes } & \multirow[t]{2}{*}{ Aging population } \\
\hline & Bad & Good & Slow & Quick & & \\
\hline \multirow[t]{2}{*}{ Target Group } & $\begin{array}{l}\text { Carer not correct target } \\
\text { group }\end{array}$ & $\begin{array}{l}\text { Everybody is } \\
\text { potential user }\end{array}$ & $\begin{array}{l}\text { Monopoly, which } \\
\text { could lead to slacking } \\
\text { off }\end{array}$ & $\begin{array}{l}\text { Niche players? We } \\
\text { have a head-start due } \\
\text { to the contacts with } \\
\text { the municipality. } \\
\text { Bundeling the best of } \\
\text { breed }\end{array}$ & $\begin{array}{l}\text { Change is not so relevant, but } \\
\text { planning is relevant(where do the } \\
\text { subsidies come from? }\end{array}$ & $\begin{array}{l}\text { Is the target group, so } \\
\text { this would be } \\
\text { favourable }\end{array}$ \\
\hline & $\begin{array}{l}\text { Possibility: } \\
\text { Education/training }\end{array}$ & & & & & \\
\hline Proposition & $\begin{array}{l}\text { Simple Interface is crucial, } \\
\text { possibility for training } \\
\text { courses }\end{array}$ & Lots of possibilities & $\begin{array}{l}\text { More space to search } \\
\text { for the right } \\
\text { proposition }\end{array}$ & $\begin{array}{l}\text { Differentiate more, } \\
\text { more focus before } \\
\text { acting, growth }\end{array}$ & $\begin{array}{l}\text { But, now all regulation around this } \\
\text { topic, including the healthcare act }\end{array}$ & \\
\hline Technology & \begin{tabular}{|l|} 
Interface should be \\
intuitive, Adapt to level of \\
users
\end{tabular} & $\begin{array}{l}\text { GUI with more } \\
\text { functionalities for ICT } \\
\text { platform }\end{array}$ & Good availability & \begin{tabular}{|l|} 
Tech should be state- \\
of-the-art, else \\
competitors will profit
\end{tabular} & $\begin{array}{l}\text { Could this new form of technology } \\
\text { change the course of regulation }\end{array}$ & \\
\hline \multirow[t]{2}{*}{$\begin{array}{l}\text { Actors and } \\
\text { position/roles }\end{array}$} & $\begin{array}{l}\text { Showstopper if End-user } \\
\text { cannot work with plattorm }\end{array}$ & \begin{tabular}{|l|} 
Regulation: \\
Contracts and \\
tripartite, acces levels
\end{tabular} & $\begin{array}{l}\text { Time to build up the } \\
\text { eco-system }\end{array}$ & Risk of Winner takes a & | |Other actors come into play & \\
\hline & $\begin{array}{l}\text { Possibility: Intermediary } \\
\text { supports/ guide }\end{array}$ & & & & & \\
\hline \multirow[t]{2}{*}{ Revenue Models } & Less Revenue & $\begin{array}{l}\text { More possibilties, } \\
\text { better advice }\end{array}$ & \begin{tabular}{|l|} 
Market size and less \\
than expected \\
revenues
\end{tabular} & $\begin{array}{l}\text { Smaller slice of the pie, } \\
\text { but think of other } \\
\text { revenue models(data) }\end{array}$ & $\begin{array}{l}\text { If the visiting nurse los } \\
\text { to regulation changes }\end{array}$ & \\
\hline & $\begin{array}{l}\text { Possibility: } \\
\text { Education/training new } \\
\text { revenue stream }\end{array}$ & & & & & \\
\hline
\end{tabular}

Fig. 3 An excerpt from the stress test results of Zo-Dichtbij's BM

interdependencies is lost, however. The other option is to color code stakeholders' interests on one common Canvas. In our workshop the color coding method was applied.

It appears that exogenous uncertainties like regulation are hindering the market/hindering the market potential of Fairshare's service. These uncertainties set extremes to revenue sharing within the ecosystem (see Fig. 6). In the end, the company sees uncertain, or rather, unpredictable governmental action as the biggest threat to the tentative BM, especially in scenarios that restrict the number of licenses. The second major stress factor is the immediate and intense response by the incumbent, but also the possible entrants of other competing firms. The Business Model elements that needed close attention and modification after the analysis and conclusion were Cost Structure, Key Partners, Key Resources, and Customer Segments.

The company found Stress Testing most useful, because the sessions led to deeper insight into entering unserved new markets with their BM. The Stress Test and questionnaire data showed that the new market strategy of FairShare is viable, but radical changes must be made to prepare for critical uncertainties. "Our Business Model needs to be sharpened anyway, each year" and "The BM remains useful, but we have to develop a new improved product and introduce it on the market", which implies the creeping in of a sustaining strategy - just in case.

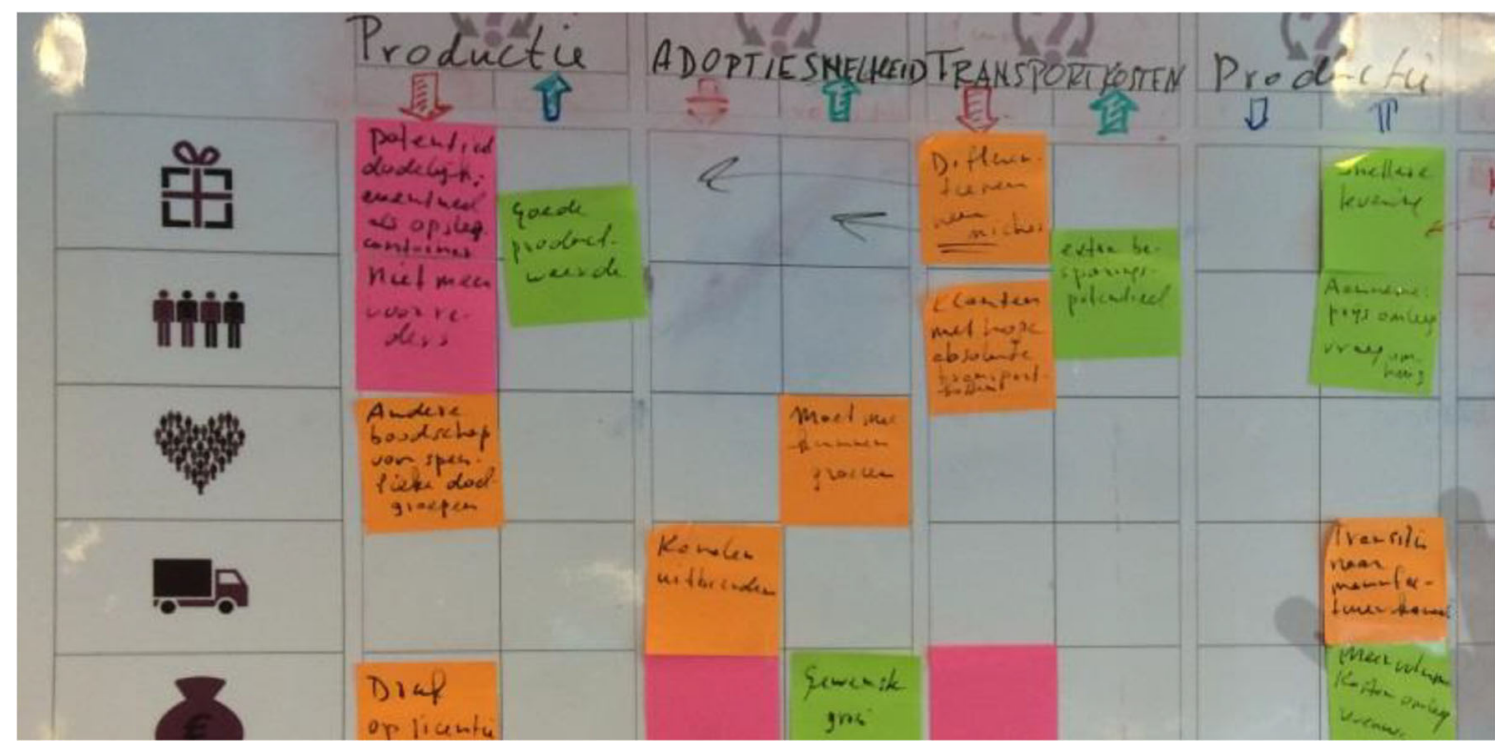

Fig. 4 Stress testing of the HCI business model 


\begin{tabular}{|c|c|c|c|c|c|c|c|c|}
\hline & \multicolumn{2}{|c|}{ Quality production } & \multicolumn{2}{|c|}{ Adoption speed } & \multicolumn{2}{|c|}{ Transportcosts } & \multicolumn{2}{|c|}{ Manufacturing speed } \\
\hline & Go down & Go up & Go down & Go up & Go down & Go up & Go down & Go up \\
\hline Value Proposition & $\begin{array}{l}\text { Potentially lethal: } \\
\text { storage is a possibility }\end{array}$ & Good product value & $\begin{array}{l}\text { Differentiate to } \\
\text { niches }\end{array}$ & $\begin{array}{l}\text { Differentiate to } \\
\text { niches }\end{array}$ & Differentiate to niches & \begin{tabular}{|l} 
Extra cost- \\
cutting \\
potential
\end{tabular} & & $\begin{array}{l}\text { Quick delivery(Quality- } \\
\text { level should be kept on } \\
\text { the same level) }\end{array}$ \\
\hline $\begin{array}{l}\text { Customer } \\
\text { Segments }\end{array}$ & $\begin{array}{l}\text { Not for Shipping lines } \\
\text { anymore }\end{array}$ & Good product value & $\begin{array}{l}\text { Customers with } \\
\text { absolute high costs }\end{array}$ & & & $\begin{array}{l}\text { Extra cost- } \\
\text { cutting } \\
\text { potential }\end{array}$ & & $\begin{array}{l}\text { Assumtion: Price goes } \\
\text { down, demand goes up }\end{array}$ \\
\hline \begin{tabular}{|l|} 
Customer \\
Relationship
\end{tabular} & $\begin{array}{l}\text { Different message for } \\
\text { specific target-groups }\end{array}$ & & & $\begin{array}{l}\text { Should be able to } \\
\text { grow accordingly }\end{array}$ & & & & \\
\hline Channels & & & Expand channels & & & & & $\begin{array}{l}\text { Transition to } \\
\text { manufacturer channel }\end{array}$ \\
\hline Revenue streams & Pressure on License Fee & & & desired growth & & & & $\begin{array}{l}\text { Higher volume, costs go } \\
\text { down, revenue goes up }\end{array}$ \\
\hline Key activities & \begin{tabular}{|l} 
Extra resources on \\
Quality Control
\end{tabular} & $\begin{array}{l}\text { Quality Control as a } \\
\text { Service }\end{array}$ & $\begin{array}{l}\text { Extra resources on } \\
\text { sales }\end{array}$ & $\begin{array}{l}\text { challenge on quality } \\
\text { vs manufacturing }\end{array}$ & $\begin{array}{l}\text { Matching activities } \\
\text { with differentiating }\end{array}$ & & & $\begin{array}{l}\text { Growth employees, } \\
\text { room for new services }\end{array}$ \\
\hline Key Resources & Production shift? & & & & & & & \\
\hline Key Partners & & & \begin{tabular}{|l} 
Investors \\
manufacturers
\end{tabular} & & & & & \\
\hline Cost Structure & Cheaper? & \begin{tabular}{|l|}
$\begin{array}{l}\text { Too expensive, } \\
\text { and/or too good for } \\
\text { spare parts }\end{array}$ \\
\end{tabular} & & & & & & $\begin{array}{l}\text { Production costs go } \\
\text { down }\end{array}$ \\
\hline
\end{tabular}

Fig. 5 The stress test result for the HCI business model

\section{Findings and discussion}

Our BM Stress Testing experiments of real-world business cases turned out to be useful in identifying potential vulnerabilities of present and planned business models. Our experiments indicate that Stress Testing might well be applicable for analyzing business models in different market strategies Sustaining High- and Low-End product disruptions, and New-Market entry disruption. The method helps to identify relevant and critical issues of BM components (see Table 2.) and leads toward having agile and iterative BMI, as suggested in a few recent studies. The BM Stress Test method we used is a further development of the research presented by Bouwman et al. 2012.

The research data were gathered from the Stress Test workshops and from pre- and post-questionnaires. The immediate and posterior feedbacks were most positive, because the Stress Tests opened realistic alternative views of the present or tentative business model by bringing in strategic market contexts. As we expected, Stress Testing appeared as an agile way of working, since the Business Model and its components can be Stress Tested multiple times within a short period, mainly dependent of course on the availability of relevant stakeholders. Due to the use of a (contrasted) scenario method, we can see under which conditions the BM components are most affected. Furthermore, BM Stress Testing contributes to the agility of BMI because the Stress Test gives clearer grounds to managers for versatile, flexible responses to possible changes in market conditions, competitor behavior, changes in regulation, or emerging technologies that may have an impact on each BM element. Also, the role of regulation and government as an unpredictable market maker is seen as a

\begin{tabular}{|c|c|c|c|c|c|c|c|}
\hline & \multicolumn{3}{|c|}{ Availability regulation and licenses } & \multicolumn{2}{|l|}{ profit remittance } & \multicolumn{2}{|c|}{ Competitor incumbent } \\
\hline & \multicolumn{2}{|c|}{ Negative } & \multirow[t]{2}{*}{ Positive } & \multirow[t]{2}{*}{ Low } & \multirow[t]{2}{*}{ High } & & \\
\hline Value Proposition & $\begin{array}{l}\text { Proposition: A lot of } \\
\text { Gambling as a marketing } \\
\text { tool, as an alternative }\end{array}$ & & & & & & \\
\hline & & & & & & Lobby + & \\
\hline \multirow[t]{2}{*}{ Customer Segments } & $\begin{array}{l}\text { Smaller customer } \\
\text { segment, export niche } \\
\text { exploits }\end{array}$ & $\begin{array}{l}\text { Change target } \\
\text { groups }\end{array}$ & & $\begin{array}{l}\text { High remittance to charities is } \\
\text { more attractive for them, but } \\
\text { consumers don't care }\end{array}$ & & $\begin{array}{l}\text { Charities are pressurized by } \\
\text { the Postcodeloterij(200 } \\
\text { registered charities get money } \\
+ \text { Lock in) }\end{array}$ & $\begin{array}{l}\text { Because of } \\
\text { dissatisfaction of } \\
\text { charities, focus on } \\
\text { mistreated } \\
\text { charities(Donations +) }\end{array}$ \\
\hline & & & & More prices for consumers & & Lobby - & \\
\hline \multicolumn{8}{|l|}{ Customer Relationship } \\
\hline Channels & & & & More profits & & & \\
\hline Revenue streams & $\begin{array}{l}\text { Less remittance, more } \\
\text { sponsoring } \\
\text { possibilities(Less than } \\
\text { 100K€) }\end{array}$ & & & $\begin{array}{l}\text { But this is the case when } \\
\text { there is a difference in license } \\
\text { types }\end{array}$ & & Pressurized & \\
\hline Key activities & & & & Deal with it Lean \& Mean & & & \\
\hline Key Resources & $\begin{array}{l}\text { Hope for a Semi- } \\
\text { Permanent license }\end{array}$ & & & & & & \\
\hline Key Partners & Pushed out of the system & & & Sponsors are important & & $\begin{array}{l}\text { Lobby starts to be in favor of } \\
\text { FairShare }\end{array}$ & $\begin{array}{l}\text { Brothers in Arms, } \\
\text { parties in resistance to } \\
\text { the Postcode Lotery }\end{array}$ \\
\hline Cost Structure & & & & & & Legal Costs & \\
\hline
\end{tabular}

Fig. 6 The Stress test result for the FairShare BM 
Table 2 Summary of core findings

\begin{tabular}{|c|c|c|c|c|}
\hline & & $\begin{array}{l}\text { Zo-Dichtbij } \\
\text { Low-end entry }\end{array}$ & $\begin{array}{l}\text { HCI Holland container innovation } \\
\text { Sustaining }\end{array}$ & $\begin{array}{l}\text { FairShare } \\
\text { New market }\end{array}$ \\
\hline \multirow[t]{2}{*}{$\begin{array}{l}\text { Uncertainties influencing } \\
\text { BM identified in Stress Testing }\end{array}$} & Internal & - Cost efficiency & $\begin{array}{l}\text {-Manufacturing lead time } \\
\text {-Quality of the end product }\end{array}$ & -Revenue sharing \\
\hline & External & $\begin{array}{l}\text { - Regulation of market } \\
\text {-Privacy statutes } \\
\text { - Competition by imitators } \\
\text {-Aging, digital skills }\end{array}$ & $\begin{array}{l}\text {-Adoption speed } \\
\text { - Transportation costs } \\
\text {-Market growth }\end{array}$ & $\begin{array}{l}\text { - Regulation of market } \\
\text { - Countermeasures by incumbents } \\
\text { - Other new entrants }\end{array}$ \\
\hline Agility required regarding & & $\begin{array}{l}\cdot \text { Customer segments } \\
\text {-Revenue streams, } \\
\text { pricing } \\
\cdot \text { Key partners }\end{array}$ & $\begin{array}{l}\text { - Customer segments } \\
\text {-Revenue streams } \\
\text {-Key activities (e.g. product development) }\end{array}$ & $\begin{array}{l}\cdot \text { Customer segments } \\
\cdot \text { Revenue streams } \\
\cdot \text { Key partners } \\
\cdot \text { Key resources }\end{array}$ \\
\hline
\end{tabular}

problem by companies with Low-End disruption or NewMarket -strategies, alleviating the need for extensive environment scanning (e.g., PESTLE, STEEPLED, etc.).

Our case studies also show that it is important for these companies to understand their market strategy environment to direct their BMI resources correctly. For example, in the sustaining strategy case, it is vital to improve the quality and production speed of existing products for its existing customer base, even with the help from low entrants, so as to economize product development costs during market making and the expansion stage for its existing products. On the other hand, in Low-End -entry and New-Market strategies, a fast iteration Stress Test-BMI cycle can target better matching technological solutions to needs and innovate more profitable business models than imitators and incumbents can do.

Interestingly, there are some common Business Model components that appear vulnerable in Stress Testing of all three case companies and independently so from the strategic intent: In all cases, market segmentation and revenue streams require agile attention and response (see Table 2). Moreover, the Stress Testing shows that the cost structure, channels, and the customer relationship are considered the least problematic. Although the costs are considerable for building platforms (Zo-Dichtbij \& FairShare) and HCI also has high intellectual capital and product development costs, these costs were not the most discussed topics. This is especially true for the entrants, where key partners of the (service) ecosystem need more attention and rapid redesign (e.g., Dedehayir et al. 2014). The limited attention given to these topics may be explained by the fact that they are 'resources' under control of the start-up and the early stage companies themselves.

In addition to the expected gain in BMI speed, thanks to the iterative way of working, Stress Testing also gives practical advice on where to focus during the next development cycles of BM innovation.

\section{Conclusions and future Research}

This paper explores how the use of a specific Business Modelling method, BM Stress Testing, contributes to agility in BM innovation. We utilize a BM Stress Test method which helps companies to assess the impact of future scenarios to their BM. The method allows companies to systematically analyze how potential changes in their business environment may jeopardize their business model, and to identify the most affected elements of their BM. The method also requests companies to reason why a particular BM element is critical for the $\mathrm{BM}$ robustness, and this leads them to reconsider and redesign their BM. Therefore we can claim that BM Stress Testing persuades companies to be more agile in their BMs innovation process.

We illustrated the use of Stress Testing with three selected action design cases. In our real-world experiments, the involved companies found Stress Testing as an important, useful, and well-structured approach to identify both the viability and the vulnerability of existing and planned business models in their strategic context. By using the BM Stress Testing method, the BM innovation not only becomes more agile, but also robust and versatile. It helps to handle uncertainties in an agile, iterative, and systematic way. The postulated and indicated need for rapid iteration speaks to increasing BM agility with Stress Testing, especially for rapid identification of customer segments and revenue streams.

This study also has its limitations. Our design cases concerned BM Stress Testing in three companies, each representing differing market entry strategies. Therefore, we cannot generalize our research results to a certain population, but instead we aimed to produce actionable knowledge, that is, rules of thumb that can be used by either people or organisations to solve problems (Metcalfe and Lynch 2002; Heikkilä and Heikkilä 2013). Our results show how the Stress Testing method can be utilized by companies, regardless of their market entry strategies, when they want to deal with BM design or 
innovation and want to assess possible outcomes under alternative future scenarios.

Further research to generalize our findings on the role of agility in business model innovation is clearly needed. The Stress Test method is being developed and utilized quite extensively in several cases, and currently, we are in the process of searching for patterns so we can understand the underlying causalities (Heikkilä et al. 2016). Our intention is to confirm these findings with a larger dataset collected from various cases in the forthcoming years, preferably using quantitative methods. For practical relevance, we are encouraged as well to use these early results to develop more lightweight and agile BM methods and tools (see businesmakeover.eu) and the different market entry situations and ways of business modelling. Pre-filled options, video-instructions, and a more game-based approach can be explored to make the tool a self-service tool that can meet the vast target group of SMEs and growth ventures.

Acknowledgement We acknowledge the generous support of the European Commission. This project received funding from the European Union's Horizon 2020 Research and Innovation Program under Grant Agreement No 645791.

We also acknowledge the support from René van Buuren for tool development and the support Timothy Sealy for support software.

Open Access This article is distributed under the terms of the Creative Commons Attribution 4.0 International License (http:// creativecommons.org/licenses/by/4.0/), which permits unrestricted use, distribution, and reproduction in any medium, provided you give appropriate credit to the original author(s) and the source, provide a link to the Creative Commons license, and indicate if changes were made.

\section{References}

Beck, K., Beedle, M., Bennekum, A. V., Cockburn, A., Cunningham, W., Fowler, M., Grenning, J., Highsmith, J., Hunt, A., Jeffries, R., Kern, J., Marick, B., Martin, R. C., Mellor, S., Schwaber, K., Sutherland, J. \& Thomas, D. (2001), Manifesto for Agile Software Development, available at: http://agilemanifesto.org/ (Accessed May 2016).

Beck, K., \& Andres, C. (2005). Extreme programming explained: Embrace change. Boston: Addison-Wesley.

Bock, A. J. \& George, G. (2014). Agile business model innovation. The European Business Review, June 29.

Bouwman, H., De Reuver, M., Solaimani, S., Daas, D., Haaker, T., Janssen, W., Iske, P., \& Walenkamp, B. (2012). Business models, tooling and research agenda. In R. Clark, A. Pucihar, \& J. Gricar (Eds.), The first 25 Years of the bled conference. Moderna Organizacija: Kranj.

Bouwman, H., de Vos, H., \& Haaker, T. (2008). Mobile service innovation and business models. Berlin: Springer-Verlag.

Bouwman, H., de Reuver, M., Hampe, F., Carlsson, C., \& Walden, P. (2014). Mobile R\&D Prototypes - what is hampering market implementation? International Journal of Innovation and Technology Management, 11(1).

Bullinger, H.-J., Fähnrich, K.-P., \& Meiren, T. (2003). Service engineering-methodical development of new service products. International Journal of Production Economics, 85(3), 275-287.
Casadesus-Masanell, R., \& Ricart, J. E. (2010). From strategy to business models and on to tactics. Long Range Planning, 43(2), 195-215.

Chan, L.-K., \& Wu, M.-L. (2002). Quality function deployment: a literature review. European Journal of Operational Research, 143(3), 463-497.

Chesbrough, H. (2010). Business model innovation. Opportunities and barriers. Long Range Planning, 43(2), 354-363.

Chou, S-W., Hsu, C.S., Min, H-T., Chiang, C-H., \& Chang, Y-C. (2014). Understanding competitive performance of Software-as-a-Service (SAAS) - The competitive dynamics perspective. PACIS 2014 Proceedings. Paper 362.

Christensen, C.M., (1997). The Innovator's dilemma: When new technologies cause great firms to fail. Harper Business.

Christensen, C. M. (2006). The ongoing process of building a theory of disruption. The Journal of Product Innovation Management, 23(1), $39-55$.

Christensen, C. M., Grossman, J. H., \& Hwang, J. (2009). The Innovator's prescription: A disruptive solution for health care. New York: McGraw-Hill.

Christensen, C. M., Raynor, M., \& McDonald, R. (2015). What is disruptive innovation?, Harvard Business Review. Dec., 2015, 44-53.

Coad, P., De Luca, J., \& Lefebre, E. (1999). Java modeling in color. Englewood Cliffs: Prentice Hall.

Cohen, L. (1995). Quality function deployment: How to make QFD work for you. Reading, Mass: Addison-Wesley.

Conboy, K. (2009). Agility from first principles: reconstructing the concept of agility in information system development. Information Systems Research., 20(3), 329-354.

Cooper, R. G. (1990). Stage gate systems: a new tool for managing new products. Business Horizons, 33(3), 44-54.

Cortimiglia, M. N., Ghezzi, A., \& Frank, A. G. (2016). Business model innovation and strategy making nexus: evidence from a crossindustry mixed-methods study. $R \& D$ Management, 46(3), 414-432.

DaSilva, C. M., \& Trkman, P. (2013). Business model: what it is and what it is not. Long Range Planning, 47(6), 379-389.

Cole, R., Purao, S., Rossi M., \& Stein M. (2005). Being proactive: When action design meets design research. ICIS proceedings, http://aisel. aisnet.org/icis2005/27/.

Dedehayir, O., Ortt, J. R., \& Seppänen, M. (2014). Reconfiguring the innovation ecosystem: An explorative study of disruptive change, International conference on engineering, technology and innovation 2014 (pp. 23-25). Italy: Bergamo.

De Reuver, M. Bouwman, H., \& MacInnes, I. (2009). Business model dynamics for start-ups and innovating eBusinesses. International Journal of Electronic Business, 7(3), 269-285.

De Reuver, M., Bouwman, H., \& Haaker, T. (2013). Business model roadmapping: a practical approach to come from an existing to a desired business model. International Journal of Innovation Management, 17(01).

De Toni, A., \& Tochia, S. (1998). Manufacturing-flexibility: a literature review. International Journal of Production Research., 36(6), 1587-1617.

Doz, Y.L., \& Kosonen, M. (2008). Fast strategy: how strategic agility will help you stay ahead of the game. Pearson Education.

El Sawy, O. A., \& Pereira, F. (2012). Business modelling in the dynamic digital space: an ecosystem approach. Springer Science \& Business Media.

Fritscher, B., \& Y. Pigneur (2011). Business IT alignment from business model to enterprise architecture. Proceedings of the 6th International Workshop on BUSinness/IT ALignment and Interoperability (Busital), An ancillary workshop of CAISE 2011, London, June, pp. 4-15.

Fritscher, B., \& Pigneur, Y. (2015). Business IT alignment between business model and Enterprise architecture with a strategic perspective. International Journal of Information System Modeling and Design, 6(1), 1-23. 
Galbraith, J. R. (2014). Designing organizations: Strategy, structure, and process at the business unit and Enterprise levels (3rd ed.). JosseyBass .352 pages

Goldstein, S., Johnston, R., Duffy, J., \& Rao, J. (2002). The service concept: the missing link in service design research? Journal of Operations Management, 20(2), 121-134.

Heikkilä, M. (2010). Coordination of complex operations over organisational boundaries, Ph.D. Thesis, University of Jyväskylä, Jyväskylä Studies in Computing 111.

Heikkilä, M., \& Heikkilä, J. (2013). Collaborative business model innovation process for networked services. In J. Järveläinen, H. Li, A.M. Tuikka, \& T. Kuusela (Eds.), Co-created Effective, Agile, and Trusted eServices (in Series: Lecture Notes in Business Information Processing, 155, 133-147).

Heikkilä, J., Tyrväinen, P. \& Heikkilä, M. (2010). Designing for performance - a technique for business model estimation. Seppä, M., Helander, N. \& Ilvonen, I. (eds.) Proceedings of EBRF, Research Forum to Understand Business in Knowledge Society.

Heikkilä, J., Bouwman, H., \& Heikkilä, M. (2015). Business modelling agility: turning ideas into business. 28th Bled eConference \#eWellbeing, June 7.-10., 2015. Bled, Slovenia, 43-54.

Heikkilä, M., Bouwman, H., Heikkilä, J., Haaker, T., Lopez Nicolas, C., \& Riedl, A., (2016). Business model innovation paths and tools. 29th Bled eConference, Digital Economy, in June 19-22, 2016. Bled, Slovenia.

Hevner, A. R., March, S. T., Park, J., \& Ram, S. (2004). Design science in information systems research. MIS Quarterly, 28(1), 75-105.

Itami, H., \& Nishino, K. (2010). Killing two birds with one stone: profit for now and learning for the future. Long Range Planning, 43(2), 364-369.

Karni, R. \& Kaner, M. (2007). An engineering tool for the conceptual design of service systems. In Spath, D. \& Fähnrich, K-P. (eds.) Advances in Services Innovations. Springer. 65-85.

Keijzer-Broers, W., Florez-Atehortua, L., \& de Reuver, M. (2015). Prototyping a Health and Wellbeing Platform in a Living Lab Setting. In D. Vogel, X. Guo, C. Barry, M. Lang, H. Linger, \& C. Schneider (Eds.), Information Systems Development: Transforming Healthcare through Information Systems (ISD2015 Proceedings).

Kim, W. C., \& Mauborgne, R. (2005). Blue Ocean strategy: How to create uncontested market space and make the competition irrelevant. Harvard Business School Press .256 pages.

Kniberg, H. \& Iversson, A. (2012). Scaling Agile@ Spotify with Tribes, Squads, Chapters \& Guilds. Entry posted November 12.

Lee, G., \& Xia, W. (2010). Toward agile: an integrated analysis of quantitative and qualitative field data on software development agility. MIS Quarterly, 34(1), 87-114.

Lindgren, P., \& Rasmussen, O. H. (2013). The business model cube. Journal of Multi Business Model Innovation and Technology., 1(3), 135-182.
McGrath, R. G. (2010). Business models: a discovery- driven approach. Long Range Planning, 43(2), 247-261.

Menor, L., Tikonda, M., \& Sampson, S. (2002). New service development: areas for exploitation and exploration. Journal of Operational Management, 20(2), 135-157.

Metcalfe, M., \& Lynch, M. (2002). A critique of generalizability in interpretive research. Australasian Journal of Information Systems, 10(1).

Miles, M.B., Huberman, A.M., \& Saldaňa J., (2013). Qualitative Data Analysis: A Methods Sourcebook. Sage.

Norman, D. (1998). The invisible computer: Why good products can fail, the personal computer is so complex and information appliances are the solution. London, England: MIT Press.

Osterwalder, A. \& Pigneur, Y. (2010). Business Model Generation: A Handbook for Visionaries, Game Changers, and Challengers. Wiley, $288 \mathrm{p}$.

Otto, B., Bärenfänger, R., \& Steinbuss, S., (2015). Digital Business Engineering: Methodological Foundations and First Experiences From the Field. 28th Bled eConference \#eWellbeing, June 7.-10., 2015. Bled, Slovenia, 58-76.

Oxford Living Dictionaries, (2016). https://en.oxforddictionaries. $\mathrm{com} /$ definition/stress test.

Schwaber, K., \& Beedle, M. (2002). Agile software development with scrum. Upper Saddle River: Prentice-Hall.

Sein, M. K., Henfridsson, O., Purao, S., Rossi, M., \& Lindgren, R. (2011). Action design research. MIS Quarterly, 35(1), 37-56.

Sherehiy, B., Karwowski, W., \& Layer, J. K. (2007). A review of enterprise agility: concepts, frameworks, and attributes. International Journal of Industrial Ergonomics., 37(5), 445-460.

Shostack, L. G. (1984). Designing services that deliver. Harvard Business Review., 62(1), 133-139.

Stapleton, J. (1997). DSDM: Dynamic systems development method. Harlow: Addison Wesley.

Takeuchi, H., \& Nonaka, K. (1986). The new new product development game. Harvard Business Review, 64(1), 137-146.

Teece, D. J. (2010). Business models, business strategy, and innovation. Long Range Planning, 43(2), 172-194.

Van Aken, J., \& Romme, G. (2009). Reinventing the future: adding design science to the repertoire of organization and management studies. Organization Management Journal, 6(1), 5-12.

Vargo, S. L., \& Lusch, R. F. (2004). Evolving to a new dominant logic for marketing. Journal of Marketing, 68(1), 1-17.

Verschuren, P., \& Hartog, R. (2005). Evaluation in design-oriented research. Quality and Quantity, 39(6), 733-762.

Volberda, H. W. (1996). Towards the flexible form: how to remain vital in hypercompetitive environments. Organization Science, 7(4), 359-374.

Volberda, H. W. (2004). De Flexibele onderneming. Strategieën voor succesvol concurreren. (the flexible firm. Strategies for competition). Deventer: Kluwer. In Dutch.

Zott, C., \& Amit, R. (2010). Business model design: an activity system perspective. Long Range Planning, 43(2), 216-226. 